\title{
Martín Almagro-Gorbea, Los Celtas. Imaginario, mitos y literatura en España, Almuzara, Madrid, 2018, 422 pp.
}

A la eventual pregunta de si el arqueólogo nace o se hace, en el caso de Martín Almagro-Gorbea habría que decir claramente que se nace y que se hace. Hijo del eminente arqueólogo Martín Almagro, Martín iunior creció literalmente junto al imponente yacimiento de Ampurias (Gerona) en la casa-museo de esta localidad, junto a ánforas, epígrafes, columnas y brazaletes, entre iberos, griegos y romanos. Jovencísimo Catedrático por oposición de la Universitat de Valéncia y después de la Complutense de Madrid y, entre otras diversas responsabilidades, efímero director del Museo Arqueológico Nacional y perpetuo Anticuario de la Real Academia de la Historia, su predestinada vocación se ha materializado en casi un millar de publicaciones sobre variados temas, siempre relacionados con la Antiguiedad y siempre también desde perspectivas metodológicas inquietas y novedosas, prestando especial atención a los fenómenos de continuidad histórica de lo más antiguo y a su pervivencia, materializada frecuentemente en la periferia - popular, rural, tradicional...- del mundo actual, algo que quizá deba también a sus raíces enriñonadas en la serranía de Albarracín (Teruel), uno de los puntos más a desmano de nuestra península. Hace unos pocos años estos atajos o transcaminos - si es que queremos traducir literalmente la palabra griega método (méthodos) - le condujo hasta su Literatura hispana prerromana. Creaciones literarias fenicias, tartesias, celtas y vascas (Real Academia de la Historia, Madrid, 2013) de más de 500 páginas. Partiendo de aquellos mismos expedientes heurísticos, el arqueólogo Almagro-Gorbea excava en la tradición y el folclore para poder internarse en el mundo incluso ideológico de las comunidades antiguas que conforman nuestro primario referente. Cotejando siempre sus datos con la iconografía del silente material arqueológico conservado, de cuya hermenéutica es un auténtico maestro, y comparando con la literatura tradicional en las diversas lenguas célticas, Almagro inquiere el substrato prerromano en el palimpsesto oral de nuestros cuentos, leyendas $-\mathrm{o}$, mejor: oyendas de nuestra preliteratura u oralidad tradicional y cómo de aquí pasaron a creaciones escritas, textuales, literarias. Tras una extensa y actualizada presentación de la arqueología, historia y literatura célticas (13-57), Almagro analiza el posible trasfondo céltico en numerosos cantares y romances de épocas diversas: de Jaun Zuría, de Fernán González, de los siete infantes de Lara, del conde Arnaldos (159-318)... hasta llegar a las Leyendas de Gustavo A. Bécquer (385-414). Una sección a modo de monografía está dedicada a tratar la pervivencia del tópos de la «triple muerte» — por tierra, mar y airedesde la romana Pharsalia del hispano Lucano hasta las leyendas conservadas en nuestra tradición popular o en el «literario» Libro del Buen Amor. Y así, por ejemplo, tras haber quedado ya hace tiempo expuesta por otros la superficial capa cristiana-germánica en el Cantar del Mío Cid y su interior envoltorio islámico-árabe, pasma ahora descubrir, de la diestra mano del autor, los ancestrales elementos pagano-célticos de esta emblemática obra de la literatura castellana (251-271).

El libro se halla profusamente ilustrado, lo que ayuda muy mucho a sus mejores comprensión y seguimiento, y contiene asimismo centenares de notas, preferentemente de referencias bibliográficas, pues carece propiamente del clásico elenco bibliográfico final, sin embargo y aunque más estético, el formato elegido de presentar tantas notas al final de cada capítulo, no contribuye a agilizar de su lectura. Resultan disculpables 
algunas erratas - tres versos (447-9) de la Lucano aparecen citados (38) como dos (4489); comprable por comparable (50) - como también travesuras del dichoso corrector de textos: apud ellos [27] por apud illos; o bien inconsistencias, como la vacilación en el registro de algunos nombres propios: así, el historiador griego Posidonio, es citado en la misma página (38) como Poseidonios y como Posidonios o el hecho de que al gramático romano Festo se le asigne (39) una extraña obra abreviada como l.l. (¿?); además de otras poco clásicas acentuaciones - mejor lígur que ligur [33], drúida que druida [39], Héracles y Téseo que Heracles [42, 43] y Teseo [43]... etc., etc.

Esta obra se suma, en fin, a trabajos desafiantes como el ya imprescindible del bardo Francesco Benozzo, La tradizione smarrita. Le origini non scritte delle letterature romanze (Roma, 2007), mostrando que, pese al plúmbeo peso de la omnipresente y fulgurante literatura greco-latina, la tradición literaria de países latinos como España, Francia, Italia o Portugal deben también una buena parte de sus componentes más singulares a esa previa y pervivida tradición verbal básicamente céltica en muchos casos.

Aquí y así, desvelando esta plural estratigrafía de tantas obras, buscando esa tradición, más que perdida (smarrita), sepulta y enterrada, Almagro sigue actuando esencialmente como un arqueólogo, un arqueólogo del arte verbal, reconstruyendo a base de fragmentos materiales de una u otra índole lo que pudo ser un corpus ancestralísimo de narraciones propias o al menos especialmente características del antiguo mundo céltico - seguramente su componente mayoritario y más antiguo- de la península Ibérica, cuyas lenguas fueron absorbidas por el latín, pero cuyos cuentos, imaginarios, mitos o supersticiones perduraron de alguna manera en la viva y oral tradición de nuestros mayores. Si la Arqueoglotología o Lingüística que se ocupa de la reconstrucción de lenguas remotas y sin testimonio escrito ha sido también definida como Lingüística forense, por el minucioso y paciente cruce de datos seguidos en la confección de la presente obra cumple a esta definirla asimismo como un brillante y pionero ejercicio de Literatura forense.

Xaverio Ballester

(Universitat de Valéncia)

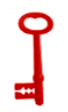

